\title{
Transformed Chronic Lymphocytic Leukemia to Diffuse Large B-Cell Lymphoma
}

National Cancer Institute

\section{Source}

National Cancer Institute. Transformed Chronic Lymphocytic Leukemia to Diffuse Large B-Cell Lymphoma. NCI Thesaurus. Code C157624.

Histologic transformation of an indolent chronic lymphocytic leukemia to an aggressive diffuse large B-cell lymphoma. 